\title{
EHMTI-0105. CGRP and VIP levels as predictors of efficacy of onabotulinumtoxin type $A$ in chronic migraine
}

\author{
E Cernuda-Morollón ${ }^{*}$, P Martínez-Camblor², E Serrano-Pertierra', D Larrosa', C Ramón', J Pascual ${ }^{1}$ \\ From 4th European Headache and Migraine Trust International Congress: EHMTIC 2014 \\ Copenhagen, Denmark. 18-21 September 2014
}

\section{Introduction}

The mechanism of action of Onabotulinumtoxin type A (onabotA) in chronic migraine $(\mathrm{CM})$ is unknown.

\section{Aim}

To analyse a potential relationship between CGRP and VIP levels and onabotA response.

\section{Methods}

CGRP and VIP levels were determined in antecubital vein samples by ELISA outside a migraine attack prior to treatment with onabotA. OnabotA was administered according to PREEMPT at least twice. A patient was considered as a moderate responder when both: 1) moderate-severe headaches were reduced by between 33-66\%; and 2) benefit in a visual scale of 0-100 was recorded between $33-66 \%$. Patients were considered as excellent responders when both items improved $>66 \%$. Those without improvement of at least one-third in the two items were considered as nonresponders.

\section{Results}

We assessed samples from $81 \mathrm{CM}$ patients and 33 controls. CGRP and VIP levels were significantly increased in CM population. CGRP and, to a lesser degree, VIP levels were significantly increased in responders vs nonresponders. For CGRP, a threshold of $72 \mathrm{pg} / \mathrm{ml}$ positively correlated with $95 \%$ of nonresponders. The probability of being a responder to onabotA was 28 times higher with a CGRP level above the threshold of $72 \mathrm{pg} / \mathrm{ml}$. Even though the sensitivity for the calculated threshold for VIP was poor, the probability that CM patients with low

${ }^{1}$ Neurology, Hospital Universitario Central de Asturias and Ineuropa, Oviedo, Spain

Full list of author information is available at the end of the article
CGRP levels will respond to onabotA was significantly higher in those patients with high VIP levels.

\section{Conclusions}

Interictal CGRP and, to a lesser degree, VIP levels are of help on predicting onabotA response. Supported by Pi11/00889 FISSS and Allergan-Eurasia MAF/ISS/NS/ $\mathrm{CM} / 003$ grants.

Conflict of interest.

\section{Authors' details}

Neurology, Hospital Universitario Central de Asturias and Ineuropa, Oviedo, Spain. ${ }^{2}$ OIB, Oficina de Investigación Sanitaria, Oviedo, Spain.

Published: 18 September 2014

doi:10.1186/1129-2377-15-S1-E24

Cite this article as: Cernuda-Morollón et al:: EHMTI-0105. CGRP and VIP levels as predictors of efficacy of onabotulinumtoxin type A in chronic migraine. The Journal of Headache and Pain 2014 15(Suppl 1):E24.

Submit your manuscript to a SpringerOpen ${ }^{\odot}$ journal and benefit from:

- Convenient online submission

- Rigorous peer review

- Immediate publication on acceptance

- Open access: articles freely available online

- High visibility within the field

- Retaining the copyright to your article

Submit your next manuscript at $>$ springeropen.com 